International Research Journal of Management, IT \& Social Sciences
Available online at https://sloap.org/journals/index.php/irjmis/
Vol. 7 No. 6, November 2020, pages: 42-53
$\begin{aligned} & \text { ISSN: 2395-7492 } \\ & \text { https://doi.org/10.21744/irjmis.v7n6.1004 }\end{aligned}$

\title{
Moral Reasoning, Whistleblowing Intention, and Audit Judgement Moderate the Effect of Ethical Sensitivity on Internal Audit Quality
}

I Dewa Nyoman Badera ${ }^{a}$ I Ketut Jati $^{\text {b }}$

Article history:

Submitted: 09 July 2020

Revised: 18 August 2020

Accepted: 27 September 2020

\section{Keywords:}

audit judgment; ethical sensitivity; internal audit quality; moral reasoning; whistleblowing intention;

\begin{abstract}
Empirical research reveals the effect of ethical sensitivity on internal audit quality but it is not always linear because of the role of several contingency factors. The purpose of this study was to determine the effect of ethical sensitivity on internal audit quality. Meanwhile, the specific objective of this research is to determine the ability of contingency factors, such as: moral reasoning, whistleblowing intention, audit judgment moderates the effect of ethical sensitivity on the quality of internal audit. The study population was the internal auditor of PT Bank BUMN "X" Kanwil Bali-Nusra, then the research sample was determined using the saturated sample method. Furthermore, the collected data were tabulated and analyzed using the Moderated Regression Analysis (MRA) technique. The results of this study reveal that: (1) Ethical sensitivity has a positive and significant effect on internal audit quality. (2) Moral reasoning strengthens the positive effect of ethical sensitivity on internal audit quality. (3) Whistleblowing intention strengthens the positive effect of ethical sensitivity on internal audit quality. (4) Audit judgment strengthens the positive effect of ethical sensitivity on internal audit quality.
\end{abstract}

International research journal of management, IT and social sciences $\left({ }_{0} 2020\right.$. This is an open access article under the CC BY-NC-ND license (https://creativecommons.org/licenses/by-nc-nd/4.0/).

Corresponding author:

I Dewa Nyoman Badera,

Economics and Business Faculty,

Udayana University, Denpasar, Indonesia.

Email address: dewaman@ymail.com

\footnotetext{
Economics and Business Faculty, Udayana University, Denpasar, Indonesia Economics and Business Faculty, Udayana University, Denpasar, Indonesia 


\section{Introduction}

State-Owned Enterprises (BUMN) and Regional-Owned Enterprises (BUMD) in Indonesia are business organizations that are oriented to the local market, because of their function as a public service, most of them are intended for the local market. In BUMN and BUMD, supervision is also required of the allocation of funds that have been provided by the central and regional governments to make it more transparent. The responsibility for managing BUMN and BUMD is not only for the government but for the Indonesian people in general (Arens, 2008). The existence of internal auditors in BUMN, especially PT. Bank X Persero. Tbk, should be able to assist management in being accountable for its management in the supervisory function and should be able to assist the company in achieving a good corporate governance system. Unfortunately, BUMN and BUMD have not been separated from several cases that could indirectly harm the state (Mukino et al., 2016).

Internal auditing is an independent assessment function that is carried out within the organization to test and evaluate the organization's internal control system. The quality of internal auditing that is carried out will be related to the competence and objectivity of the organization's internal auditor staff (Adams, 1994; Bou-Raad, 2000). As employees, internal auditors earn income from the organization where they work, this means that internal auditors are very dependent on their organization as an employer. On the other hand, internal auditors are required to remain independent as a form of their responsibilities to the public and their profession (Abdolmohammadi \& Owhoso, 2000; Windsor, 2002). Here an audit conflict arises when internal auditors carry out internal auditing activities. Internal auditors as workers in the organization being audited will encounter problems when they have to report findings that may be unfavorable in management's performance appraisal or the audit object they perform.

The ethical dilemma faced by internal auditors is unconsciously a source of ineffective internal control so that fraud still occurs. The Financial Services Authority (OJK) has processed 108 cases of banking crises in the last two years. Based on OJK statistics, banking crimes that have occurred since 2014 include credit cases (55 percent), engineering records (21 percent), embezzlement of funds (15 percent), fund transfers ( 5 percent), and asset procurement (4 percent). Nelson Tampubolon, Chief Executive of OJK Banking Supervision, said that his division of 59 cases of banking crimes has been transferred to the Department of Investigation at the OJK in 2014. Then in 2015, 23 cases were processed and this year until the third quarter of 2016, 26 cases were prosecuted (Jakarta, CNN Indonesia, 2016). Operational inefficiency and fraud involving "inside" people or white-collar crimes are part of the internal auditor's responsibility. So that there are still various cases of this kind indicating failure or need to improve the quality of internal audit (Hartanto, 2001; Jennings et al., 1998; Kang et al., 2015).

Phenomena related to fraud and irregularities undeniably raise doubts on the quality of internal audit which, if not anticipated, can result in distrust in this profession and its broad impact on the existence of the internal auditor profession. In this connection, efforts are made to reveal various factors that affect the quality of the internal audit, one of which is ethical sensitivity.

An internal auditor in carrying out an audit must have an ethical sensitivity in carrying out his duties (Futri, 2014). This ethical sensitivity is very important for each individual to measure the level of sensitivity to the values that exist both inside and outside their environment to make decisions (Herliansyah \& Elyas 2006). Several researchers have tested the effect of ethical sensitivity, such as: Eisenhardt (1989); Aisyah \& Sukirman (2015); Betti et al. (2014); Azad (1994), found that ethical sensitivity has a positive and significant effect on audit quality. The results of the research conducted by concluded that the variable ethical sensitivity affects audit quality. Meanwhile, several other researchers revealed different results, such as: Sunarsih (2017), found that ethical sensitivity did not affect audit quality.

Inconsistent research results should be presumed because other factors influence the relationship between the independent variable and the dependent variable. Govindarajan (1986), states that there may not be any unified research results depending on certain factors or better known as contingency factors. Murray \& Schlacter (1990), explains that to reconcile conflicting results, a contingency approach is needed to identify other variables that act as moderators or mediators in the research model. Several contingency variables are relevant to the effect of ethical sensitivity, three of which are moral reasoning, whistleblowing intention, and audit judgment.

Good audit quality is of course not just formed but is determined by many factors including contingency factors. Good audit quality is influenced by moral reasoning (Futri, 2014; Al-Ajmi, 2009; Christ et al., 2015). The American Institute of Certified Public Accountants (AICPA) requires auditors to exercise professional sensitivity and moral judgment in all their activities (Anderson \& Ellyson, 1986 in Basuki \& Mahrdani, 2006). According to Ahituv (1998), moral reasoning is defined as the reason that underlies someone in taking an action or the reasons that underlie someone in justifying or criticizing an act. An auditor who has high moral reasoning will be more precise in conducting audit judgment so that the resulting audit quality will also be better. Research by Cung et al. (2001), found that moral

Badera, I. D. N. ., \& Jati , I. K. (2020). Moral reasoning, whistleblowing intention, and audit judgement moderate the effect of ethical sensitivity on internal audit quality. International Research Journal of Management,

IT and Social Sciences, 7(6), 42-53. https://doi.org/10.21744/irjmis.v7n6.1004 
reasoning has a positive and significant effect on audit quality. However, it is different from the results of research conducted by Suriana (2014) and Indira (2015) which concluded that the moral reasoning variable affects audit quality.

Based on the conception and the results of empirical research that have been described, it can be seen that moral reasoning affects the quality of the internal audit, or in other words, the high moral reasoning of auditors will improve the quality of the audit. If high moral reasoning is inherent in the auditor, it should be assumed that it will increase the positive effect of ethical sensitivity on the quality of internal audit. How is the reality, depending on the results of the tests to be carried out in this study.

The next contingency factor that is thought to be able to dynamize the effect of ethical sensitivity is whistleblowing intention. In Indonesia, guidelines for the Whistleblowing System (SPP) 2008 were issued by the National Committee for Governance Policy (KNKG) to improve the quality of corporate governance implementation in Indonesia. According to the KNKG, whistleblowing is the disclosure of violations or disclosure of actions that are against the law, unethical or immoral acts, or other actions that can harm the organization and stakeholders. The importance of whistleblowing in detecting and uncovering wrongdoing that occurs in an organization has been recognized by many regulators around the world. The effectiveness of whistleblowing in disclosing fraudulent financial statements is not only recognized by accountants and regulators in the United States but also in other countries (Patel, 2003; Miceli et al., 2008).

Several studies related to whistleblowing intention have been conducted. Mustika et al. (2016), in his research, found that the whistleblowing intention of internal auditors increases the ability to detect fraud in financial statements. Dezoort (1998), in their study, revealed that whistleblowing intention can weaken the negative effect of time budget pressure on auditor performance. Astika \& Dwirandra (2017), found that whistleblowing intention increases the positive effect of fraud audit training and audit tenure on fraud detection abilities. Whether whistleblowing intention can increase the positive effect of ethical sensitivity on internal audit quality is an interesting matter to be revealed and will be tested through this research.

Furthermore, the third contingency factor that is thought to be able to moderate the effect of ethical sensitivity is audit judgment. The BPK RI Regulation (2007) emphasizes that in addition to being skeptical in the examination process, auditors also often have to use judgment to determine the competence of evidence by determining the amount and type of evidence needed to support conclusions. Hogarth \& Einhorn (1992), defines judgment as a cognitive process which is decision selection behavior. Judgment is a personal consideration or the auditor's point of view in responding to information related to audit responsibilities and risks to be faced by the auditor, which will affect the auditor's final opinion on the financial statements of an entity (Kristianti, 2012). Swart (2013), states that professional judgment is a fundamental requirement in every modern audit.

Several researchers have conducted studies related to audit judgment. Wardoyo \& Seruni (2011), in their research, revealed that there was a positive influence on the quality of audit evidence collected by auditors. Ratha \& Ramantha (2015), in her study, found that there was a positive influence on the potential of the audience in conducting audit judgments on audit quality. Suprasto et al. (2017), in their research, found that audit judgment has a positive effect on audit quality. Based on the concessions and empirical research results described above, it can be seen that audit judgment has a positive effect on audit quality. The more competent the auditors are in making audit judgment, the greater the chances of achieving good audio quality.

In contrast to research conducted by Suriana (2014); Mohd-Sanusi \& Mohd-Iskandar (2007); Cung et al. (2001); and Mustika et al. (2016), Dezoort (1998), as well as research and research by Wardoyo \& Seruni (2011) and Suprasto et al. (2017), this study tries to determine the ability to moderate three factors. contingency (moral reasoning, whistleblowing intention, and audit judgment) on the effect of ethical sensitivity on the quality of internal audit (Endicott et al., 2003). This research is expected to produce a scientific article that will be published in international journals. The research results will also be conveyed at SENASTEK 2018 or in other scientific forums.

\section{Literature review \\ Theory of reasoned action}

Theory of Reasoned Action (TRA) was first introduced by Martin Fishbein and Ajzen in Cung et al. (2001). This theory connects belief, attitude, intention, and behavior. Will is the best predictor of behavior, meaning that if you want to know what someone is going to do, the best way is to know that person's will. However, a person can make judgments based on entirely different reasons (not always voluntary). An important concept in this theory is the focus of attention (salience), which is to consider something that is considered important. Intention is determined by subjective attitudes and norms. Theory of Reasoned Action (TRA) is related to moral reasoning as moral reasons 
obtained from the learning process and scientific reasoning by someone (internal auditors), when moral considerations have been implemented properly in making every decision, the quality of work with ethical sensitivity (ethical sensitivity) to measure the level of sensitivity to the values in the audit.

\section{Attribution theory}

Attribution theory was first proposed by Heider 1978. This theory is used to develop an explanation of the ways we judge individuals differently, depending on the meaning we attribute to certain behaviors. This theory suggests that when observing the behavior of an individual, we attempt to determine whether the behavior is caused internally or externally (Raya et al., 2016). Sanusi et al. (2007), state that internal behavior is behavior that is believed to be influenced by an individual's control. Meanwhile, behavior that is caused externally is considered as a result of external causes, that is, the individual has behaved in this way due to certain situations. Attribution theory refers to the causes of an event or results obtained based on individual perceptions. In this study, attribution theory explains the effect of fraud audit training on influencing auditors in carrying out their duties and responsibilities in detecting possible fraud. By having participated in the fraud audit training (training), the auditors are expected to be able to detect fraud that may occur. According to Dharmastuti \&Wahyudi (2013), success or failure according to individual perceptions causes expectations for future actions to occur and creates emotional results. In this case, auditors who have poor experience lead to better actions in the future and will know well how materiality and skepticism should be considered, to provide the right opinion, and be able to detect fraud that may occur in financial statements.

\section{Internal auditor and audit quality}

Mulyadi (2013), Internal Audit is an auditor who works within an entity/company whose task is to find out whether the procedures and policies that have been compiled and established by management have been complied with, determine whether safeguarding the assets of the entity/organization is good or not, determine the level of effectiveness and efficiency of procedures for the activities of the organization's activities, as well as determining the reliability of the information that has been produced by the parts of the entity/organization. According to IIA, cited by Sawyer (2005), Internal Audit is an appraisal function established by an entity to examine and evaluate the activities of the entity as a service that has been provided to the company entity (Internal Auditing is an independent, objective assurance and consulting activity designed to add value and improve an organization's operations. It helps an organization accomplish its objectives by bringing a systematic, disciplined approach to evaluate and improve the effectiveness of risk management, control, and governance processes). Audit quality is the ability of an auditor to carry out his duties, wherein conducting an audit an auditor can find client errors and report them. De Angelo (1981) in Ahmed et al. (2013), audit quality is the probability that the auditor will find and report a violation in the client's accounting system. A public accountant in carrying out his audit duties must adhere to the applicable Public Accountant Professional Standards (SPAP), the hope is that the audit can reduce the misalignment of interests between management and shareholders. By adhering to the standards and principles that apply, so that the desired goal will be achieved, namely a quality audit. In a study conducted by Arisinta (2013), five things are thought to have a relationship with audit quality, namely (1) understanding of the client's accounting information system, (2) the level of timeliness of audit completion, (3) the level of compliance with SPAP, (4) the level of confidence in client statements, and (5) the level of prudence in decision making. A good audit report and produce satisfactory audit quality if a public accountant or independent auditor in carrying out their duties by upholding professional principles

\section{Hypothesis}

Ethical sensitivity and its impact on internal audit quality

Ethical sensitivity is the ability to realize ethical or moral values in an ethical decision. Ethical Sensitivity is the ability to identify ethical problems that occur. The ability of a professional to behave ethically is greatly influenced by the individual's sensitivity to ethics. An important factor in assessing ethical behavior is the awareness of individuals that they are moral agents. The individual's awareness can be assessed through the ability to be aware of ethical values in a decision, this is called Ethical Sensitivity (Aprianto \& Setiawati, 2015). Engko \& Gudono (2007), stated that the company must be able to improve a climate of openness, integrity, and accountability following the principles of improving audit quality. Azad (1994), found that ethical sensitivity has a positive and significant effect on audit quality. The results of research conducted by Betti (2014), concluded that the variable ethical sensitivity affects audit quality.

Badera, I. D. N. ., \& Jati, I. K. (2020). Moral reasoning, whistleblowing intention, and audit judgement moderate the effect of ethical sensitivity on internal audit quality. International Research Journal of Management,

IT and Social Sciences, 7(6), 42-53. https://doi.org/10.21744/irjmis.v7n6.1004 
Ega \& Siti (2013), proved in their research that ethical sensitivity has a significant positive effect on audit quality. Ahmed et al. (2013), stated that audit quality is positively influenced by the ethical sensitivity of an auditor. Based on the conceptions and empirical research results that have been described, the following research hypotheses can be developed.

H1: Ethical sensitivity has a positive effect on internal audit quality.

The effect of moral reasoning and its ability to moderate the effect of ethical sensitivity on the quality of internal audit

Moral reasoning or moral reasoning is an attempt to solve moral problems using sound logic. In sound logic, one must be able to understand well the problem at hand before deciding what kind of problem-solving to take so that it has quality results (Atqatia, 2015). The research of Mukino et al. (2016), found that moral reasoning has a positive and significant effect on audit quality. An internal auditor with a high level of moral reasoning in providing ethical perceptions of ethical violation cases will base the accountants' behavior on moral principles (Atqatia, 2015). The level of ethical sensitivity of an internal auditor is influenced by moral reasoning because moral reasoning can produce a high or low level of ethical sensitivity and can further affect the quality of an internal auditor's audit. Research by Hasnah et al. (2015), proved that moral reasoning was able to moderate the positive effect of ethical sensitivity on audit quality. Tangsakul \& Ussahawanitchakit (2015), stated that moral reasoning can strengthen the positive effect of ethical sensitivity on audit quality. Putra (2013), proves that moral reasoning strengthens the effect of ethical sensitivity on audit quality. The research of Mukino et al. (2016), found that moral reasoning was able to moderate the positive effect of ethical sensitivity on audit quality. Based on the conception and empirical research that has been described, it can be seen that moral reasoning has a positive effect on audit quality. Furthermore, it is assumed that an auditor who has adequate ethical sensitivity supported by strong moral reasoning will be more able to improve his audit quality. Thus, the following research hypothesis can be developed:

H2: Moral reasoning increases the positive effect of ethical sensitivity on the quality of internal audit.

Whistleblowing intention and its ability to moderate the effect of ethical sensitivity on internal audit quality

According to the 2008 KNKG regarding the Guidelines for Violation Reporting System - SPP (Whistleblowing System - WBS) what is meant by whistleblowing is the disclosure of acts of violations or disclosure of acts that are against the law, unethical/immoral actions, or other actions that can harm the organization or stakeholders, which is carried out by employees or organizational leaders to the leaders of other organizations or institutions who can take action on these violations. This disclosure is generally done in secret (confidential). The violation in question is an act that violates statutory regulations; related industry regulations/standards and organization's internal regulations, as well as reportable. The importance of whistleblowing in disclosing financial fraud or scandals has been widely proven in the early decades of the twenty-first century (Dyck et al., 2010). The effectiveness of whistleblowing in disclosing fraudulent financial statements is not only recognized by accountants and regulators in the United States but also in other countries (Patel, 2003; Miceli et al., 2008). Several researchers have conducted studies related to whistleblowing intention. Mustika et al. (2016), in his research, found that the whistleblowing intention of internal auditors increases the ability to detect fraud in financial statements. Dezoort (1998), in their study, revealed that whistleblowing intention can weaken the negative effect of time budget pressure on auditor performance. Astika \& Dwirandra (2017), found that whistleblowing intention increases the positive effect of fraud audit training and audit tenure on fraud detection abilities. From the explanation, it is said that whistleblowing intention has a positive effect on audit quality. Internal auditors with strong whistleblowing intentions are thought to be able to increase the positive effect of ethical sensitivity on internal audit quality. Thus, based on the conception and results of empirical research described above, the following research hypothesis can be developed:

H3: Whistleblowing intention increases the positive effect of ethical sensitivity on internal audit quality.

Audit Judgment and its ability to moderate the effect of ethical sensitivity on internal audit quality

International Standards Auditing 200, professional judgment (professional judgment) is the application of relevant knowledge and experience, in the context of auditing accounting and ethical standards, to reach appropriate decisions in situations or circumstances during an audit engagement. Hogart \& Heinhort (1992), defines judgment as a cognitive process which is the behavior of selecting decisions. Judgment (consideration) is a continuous process in obtaining information (including feedback from previous actions), the choice to act or not to act, receiving further information. 
Jamilah et al. (2007), audit judgment is the auditor's policy in determining an opinion regarding the results of the audit which refers to the formation of an idea, opinion, or estimate about an object, event, status, or another type of event. Judgment is often needed by the auditor in carrying out an audit of an entity's financial statements (Yustrianthe, 2012). Audit judgment is attached to every stage in the financial statement audit process, namely acceptance of the audit engagement, audit planning, conducting audit testing, and audit reporting. Siegel (1989) in Mutmainah (2006), states that judgment is behavior that is influenced by the perception of the situation and this is very relevant to audit quality. Several researchers have conducted studies related to audit judgment, such as: Wardoyo \& Seruni (2011), in their research revealed that there was a positive effect of auditors' professional judgment on the quality of audit evidence collected. Ratha \& Ramantha (2015), in her study, found that there was a positive influence on the potential of the audience in conducting audit judgments on audit quality. Suprasto et al. (2017), in their research, found that audit judgment has a positive effect on audit quality. Based on the concessions and empirical research results described above, it can be seen that audit judgment has a positive effect on audit quality. If an internal auditor has adequate audit judgment, he will be able to strengthen the effect of ethical sensitivity on the quality of internal audit. Based on such a logical framework, the following research hypothesis can be developed:

H4: Audit judgment increases the positive effect of ethical sensitivity on internal audit quality.

\section{Materials and Methods}

This research was conducted at PT. State-owned bank "X" which covers the Denpasar-Bali branch, including Renon, Gajah Mada, Gatot Subroto, Kuta, Tabanan, Negara, Singaraja, Gianyar, Ubud, Klungkung, and Karangasem with each branch covering the work unit, cash office, and terrace in each region, for 2017. The dependent variable used in this study is the quality of the internal audit. The independent variable in this study used the ethical sensitivity variable. Meanwhile, the moderating variables used in this study are moral reasoning, whistleblowing intention, and audit judgment.

\section{Results and Discussions}

\section{Descriptive Analysis}

Descriptive statistics in this study were tested to provide information about the characteristics of the research variables. The minimum value indicates the smallest or lowest value in a data set. The maximum value indicates the largest or highest value in a data set. The average (mean) is the most common way to measure the central value of a data distribution under study. Standard deviation is a measure that shows the standard deviation of the observed data from the average data (Ghozali, 2017).

Table 1

Descriptive statistics

\begin{tabular}{lccccc}
\hline Variable & $\mathrm{N}$ & Min & Max & Mean & $\begin{array}{c}\text { Std. } \\
\text { Deviation }\end{array}$ \\
\hline Moral Reasoning (MR) & 50 & 3.00 & 4.17 & 3.7902 & .30437 \\
Whistleblowing Intention (WI) & 50 & 3.29 & 4.71 & 3.8598 & .33450 \\
Audit Judgement (AJ) & 50 & 3.17 & 4.67 & 3.7696 & .34907 \\
Ethical Sensitivity (ES) & 50 & 2.75 & 4.00 & 3.6300 & .38213 \\
Internal Audit Quality (KAI) & 50 & 2.33 & 4.50 & 3.6092 & .48304 \\
\hline
\end{tabular}

\section{Hypothesis test}

The regression model that is made must go through the classical assumption test first so that the resulting equation meets the BLUE (Best, Linear, Unbias, Estimator) rules and then multiple linear regression analysis can be carried out. This normality test is done to test whether a regression model (the dependent variable and the independent variable or both) has a normal distribution or not. The results of the normality test show that the coefficient Value Asymp.Sig. (2tailed) 0.074 which is greater than the alpha value of 0.05 . This shows that the variables of moral reasoning,

Badera, I. D. N. ., \& Jati, I. K. (2020). Moral reasoning, whistleblowing intention, and audit judgement moderate the effect of ethical sensitivity on internal audit quality. International Research Journal of Management,

IT and Social Sciences, 7(6), 42-53. https://doi.org/10.21744/irjmis.v7n6.1004 
whistleblowing intention, audit judgment, ethical sensitivity, and quality of internal audit are normally distributed. The multicollinearity test aims to test whether the regression model finds a correlation between independent variables (Ghozali, 2017). A regression model can be said to be good if there is no multicollinearity in it. The multicollinearity test results show that all independent variables in this study, namely the use of information technology, the relevance of information technology, the satisfaction of accounting information systems, the effectiveness of accounting information systems show a tolerance value greater than 0.10 and VIF less than 10 . This indicates that no There are symptoms (free) of multicollinearity between the independent variables of moral reasoning, whistleblowing intention, audit judgment, and ethical sensitivity. The heteroscedasticity test aims to test whether in the regression model there is an inequality of variants from the residuals of one observation to another. A good regression model is one that does not contain heteroscedasticity symptoms or has a homogeneous variant. The results of the heteroscedasticity test show that all independent variables in this study, namely moral reasoning (MR), whistleblowing intention (WI), audit judgment (AJ), and ethical sensitivity (ES) show each sig values of $0.528 ; 0.502 ; 0.416$; and $0.062>0.05$. This means that there is no influence between the independent variables on absolute residuals, so the regression model used does not contain heteroscedasticity symptoms. To reveal the effect of independent variables and moderating variables using the MRA technique. The MRA test results show that Moral reasoning (MR) has a p-value of 0.001 which is smaller than the alpha of $0.05(5 \%)$ and a constant of 6.453 which means that MR has a positive and significant effect on KAI. Whistling intention (WI) has a p-value of 0.032 which is smaller than the alpha of $0.05(5 \%)$ and a constant of 2.509 which means that WI has a positive and significant effect on KAI. Audit judgment (AJ) has a p-value of 0.898 which is greater than alpha of $0.05(5 \%)$ and a constant of 0.135 which means that $\mathrm{AJ}$ has a positive but insignificant effect on KAI. Ethical Sensitivity (ES) has a p-value of 0.002 which is smaller than the alpha of 0.05 (5\%) and a constant of 14.804 which means that ES has a positive and significant effect on KAI. While the interaction of the MR moderating variable on ES has a p-value of 0.002 which is smaller than the alpha of $0.05(5 \%)$ and a constant of 0.404 which means that MR strengthens the effect of ES on KAI. The interaction of the moderating variable WI on ES has a pvalue of 0.052 which is greater than the alpha of $0.05(5 \%)$ and a constant of -0.153 which means that WI strengthens but is not significant for the effect of ES on KAI. The interaction of the moderating variable AJ on ES has a p-value of 0.892 which is greater than the alpha of $0.05(5 \%)$ and a constant of -0.010 which means that AJ strengthens but does not have a significant effect on ES on KAI.

Table 2

Moderated regression analysis test results

\begin{tabular}{|c|c|c|c|c|c|c|}
\hline \multicolumn{2}{|c|}{ Model } & \multicolumn{2}{|c|}{$\begin{array}{l}\text { Unstandardized } \\
\text { Coefficients }\end{array}$} & \multirow{2}{*}{$\begin{array}{l}\text { Standardized } \\
\text { Coefficients } \\
\text { Beta }\end{array}$} & \multirow[t]{2}{*}{$\mathrm{t}$} & \multirow[t]{2}{*}{ Sig. } \\
\hline & & B & Std. Error & & & \\
\hline \multirow[t]{8}{*}{1} & (Constant) & 214.377 & 66.965 & & -3.201 & .003 \\
\hline & MR & 6.453 & 1.828 & 4.071 & 3.531 & .001 \\
\hline & WI & 2.509 & 1.132 & 2.029 & 2.215 & .032 \\
\hline & AJ & .135 & 1.050 & .102 & .129 & .898 \\
\hline & ES & 14.804 & 4.394 & 7.811 & 3.369 & .002 \\
\hline & MR.ES & .404 & .120 & 5.575 & 3.375 & .002 \\
\hline & WI.ES & .153 & .077 & 2.761 & 1.998 & .042 \\
\hline & AJ.ES & .010 & .072 & .117 & .137 & .892 \\
\hline
\end{tabular}

a. Dependent Variable: KAI

\section{Discussion \\ Effect of ethical sensitivity on internal audit quality}

The partial test results show that ethical sensitivity has a positive and significant effect on the quality of internal audit at PT. Bank X Branch Offices in Bali Province. The relationship between ethical sensitivity and the opinion of the audit results concluded that auditors who have ethical sensitivity attitudes give an opinion on the results of the audit is more appropriate than auditors who do not (Emine et al., 2016).

The results of this study are the same as those of Azad (1994), finding that ethical sensitivity has a positive and significant effect on audit quality. The results of research conducted by Betti (2014), concluded that the variable ethical sensitivity affects audit quality. Ega \& Siti (2013), proved in their research that ethical sensitivity has a significant 
positive effect on audit quality. Ahmed et al. (2013), stated that audit quality is positively influenced by the ethical sensitivity of an auditor.

The partial test results show that moral reasoning has a positive and significant effect on the quality of internal audit at PT. Bank X Branch Offices in Bali Province. The relationship between moral reasoning and audit results that have moral reasoning in solving moral problems using sound logic gives better internal audit quality results (Atqatia, 2015).

The results of this study are the same as research by Mukino et al. (2016), found that moral reasoning has a positive and significant effect on audit quality. The results of research conducted by Fasial (2007), concluded that the moral reasoning variable affects audit quality. Hasnah et al. (2015) proved that audit quality is positively influenced by moral reasoning. Tangsakul \& Ussahawanitchakit (2015), stated that moral reasoning has a positive and significant effect on audit quality. Putra (2013), states that moral reasoning influences audit quality.

\section{Moral reasoning moderates the effect of ethical sensitivity on internal audit quality}

The partial test results show that moral reasoning can moderate or strengthen the positive and significant impact of ethical sensitivity on the quality of internal audit at PT. Bank X Branch Offices in Bali Province. Hasnah et al. (2015), stated that moral reasoning is the moral reason that underlies an individual in determining whether an action is justified or not. The process of moral reasoning from each individual will vary depending on the experience and intensity of interacting with the surrounding social environment to improve the quality of internal audit. The results of this study are consistent with the research of Hasnah et al. (2015), who proved that moral reasoning was able to moderate the positive effect of ethical sensitivity on audit quality. Tangsakul \& Ussahawanitchakit (2015), stated that moral reasoning can strengthen the positive effect of ethical sensitivity on audit quality. Sudarshan (2014), proves that moral reasoning strengthens the effect of ethical sensitivity on audit quality. The research of Mukino et al. (2016), found that moral reasoning was able to moderate the positive effect of ethical sensitivity on audit quality. In this study, the moderating variable Moral Reasoning is included in the quasi moderator variable, namely the variable that moderates the relationship between the independent variable and the dependent variable which is also the independent variable. The classification of MR into a pseudo moderating variable can be seen from the p-value when the partial MR test on KAI is significant and when the interaction with the ES variable on KAI has a significant p-value (Ghozali, 2016).

\section{Whistleblowing Intention moderates the effect of ethical sensitivity on internal audit quality}

The results of the moderation test show that whistleblowing strengthens the effect of ethical sensitivity on the quality of internal audit. This result is supported by research conducted by Mustika et al. (2016), who found that the whistleblowing intention of internal auditors increases the ability to detect fraud in financial statements, thereby increasing the quality of the company's internal audit. This result is also in line with Dezoort (1998), who state that whistleblowing intention can weaken the negative effect of time budget pressure on auditor performance. Besides, these results are also in line with the results of research by Astika \& Dwirandra (2017), which found that whistleblowing intention increases the positive influence of fraud audit training and audit tenure on the ability to detect fraud which in turn improves the quality of a company's internal audit. In this study, the moderating variable Whistleblowing Intention is included in the quasi moderator, which is a variable that moderates the relationship between the independent variable and the dependent variable which is also an independent variable. This can be seen from the results of the partial test of WI on KAI which has a significant p-value and during the moderating interaction with ES on KAI, it also has a significant p-value (Ghozali, 2016).

\section{Audit Judgment moderates the effect of ethical sensitivity on internal audit quality}

The results of the moderation test show that audit judgment does not moderate the effect of ethical sensitivity on the quality of internal audit. This result rejects the results of research conducted by Wardoyo \& Seruni (2011), which revealed that there was a positive influence on the quality of audit evidence collected by auditors' professional judgment. Also, these results are not in line with the results of research by Ratha \& Ramantha (2015), in her study she found a positive influence on the potential of audiences in conducting audit judgments on audit quality. This result also rejects the research results of Suprasto et al. (2017), who found that audit judgment has a positive effect on audit quality. In this study, the moderating variable Audit Judgment is included in the moderation variable homologized, which is a variable that has the potential to become a moderating variable because the p-value in the partial test of AJ

Badera, I. D. N. ., \& Jati, I. K. (2020). Moral reasoning, whistleblowing intention, and audit judgement moderate the effect of ethical sensitivity on internal audit quality. International Research Journal of Management,

IT and Social Sciences, 7(6), 42-53. https://doi.org/10.21744/irjmis.v7n6.1004 
on KAI is not significant and at the time of moderation interaction with ES on KAI has a significant p-value (Ghozali, 2016).

\section{Conclusion}

Based on the results of empirical testing and discussion, it can be concluded as follows ethical sensitivity improves internal audit quality, moral reasoning increases the effect of ethical sensitivity on internal audit quality, whistleblowing intention increases the effect of ethical sensitivity on internal audit quality, audit judgment does not increase the effect of ethical sensitivity on the quality of internal audit.

\section{Conflict of interest statement}

The authors declared that they have no competing interests.

Statement of authorship

The authors have a responsibility for the conception and design of the study. The authors have approved the final article.

Acknowledgments

We are grateful to two anonymous reviewers for their valuable comments on the earlier version of this paper. 


\section{References}

Abdolmohammadi, M. H., \& Owhoso, V. D. (2000). Auditors' ethical sensitivity and the assessment of the likelihood of fraud. Managerial Finance.

Adams, M. J. (1994). Beginning to read: Thinking and learning about print. MIT press.

Ahituv, N., Igbaria, M., \& Sella, A. V. (1998). The effects of time pressure and completeness of information on decision making. Journal of management information systems, 15(2), 153-172.

Ahmed, S., Haigh, A. M. F., de Jager, C. A., \& Garrard, P. (2013). Connected speech as a marker of disease progression in autopsy-proven Alzheimer's disease. Brain, 136(12), 3727-3737.

Aisyah, E. A., \& Sukirman, S. (2015). Hubungan Pengalaman, Time Budget Pressure, Kompensasi Terhadap Kualitas Audit Pada Kantor Akuntan Publik (KAP) Di Kota Semarang. Accounting Analysis Journal, 4(1).

Al-Ajmi, J. (2009). Audit firm, corporate governance, and audit quality: Evidence from Bahrain. Advances in accounting, 25(1), 64-74. https://doi.org/10.1016/j.adiac.2009.02.005

Anderson, G. D., \& Ellyson, R. C. (1986). Restructuring professional standards-the anderson report. Journal of Accountancy, 162(3).

Aprianto, D., \& Setiawati, E. (2015). Pengaruh Independensi, Pengalaman, Due Professional Care, Akuntabilitas Dan Time Budget Pressure Terhadap Kualitas Audit (Studi Empiris Pada Kantor Akuntan Publik Di Surakarta Dan Yogyakarta) (Doctoral dissertation, Universitas Muhammadiyah Surakarta).

Arens, A. A., Elder, R. J., \& Beasley, M. S. (2008). Auditing dan jasa Assurance. Jakarta: Erlangga.

Arisinta, O. (2013). Pengaruh Kompetensi, Independensi, Time Budget Pressure, dan Audit Fee Terhadap Kualitas Audit Pada Kantor Akuntan Publik di Surabaya. Jurnal Ekonomi dan Bisnis Airlangga (JEBA)| Journal of Economics and Business Airlangga, 23(3).

Astika, I. B. P., \& Dwirandra, A. A. N. B. (2017). on Fraud Detection Capabilities.

Azad, A. N. (1994). Time budget pressure and filtering of time practices in internal auditing. Managerial Auditing Journal.

Basuki, B., \& Mahardani, K. Y. (2006). Pengaruh tekanan anggaran waktu terhadap perilaku disfungsional auditor dan kualitas audit pada kantor akuntan publik di Surabaya. Jurnal Manajemen, Akuntansi \& Sistem Informasi, 6(2), 203-223.

Betti, M., Galano, L., \& Vignoli, A. (2014). Comparative analysis on the seismic behaviour of unreinforced masonry buildings with flexible diaphragms. Engineering Structures, 61, $195-208$. https://doi.org/10.1016/j.engstruct.2013.12.038

Bou-Raad, G. (2000). Internal auditors and a value-added approach: the new business regime. Managerial Auditing Journal.

Christ, M. H., Masli, A., Sharp, N. Y., \& Wood, D. A. (2015). Rotational internal audit programs and financial reporting quality: Do compensating controls help?. Accounting, Organizations and Society, 44, 37-59. https://doi.org/10.1016/j.aos.2015.05.004

Chung, J., \& Monroe, G. S. (2001). A research note on the effects of gender and task complexity on an audit judgment. Behavioral Research in Accounting, 13(1), 111-125.

De Angelo, L.E. (1981). Auditor Size and Audit Quality. Journal of Accounting and Economics. 3(3), $183-199$.

DeZoort, F. T. (1998). Time pressure research in auditing: Implications for practice. The Auditor's Report, 22(1), 1112.

Dharmastuti, C., \& Wahyudi, S. (2013). The effectivity of internal and external corporate governance mechanisms towards corporate performance. Research Journal of Finance and Accounting, 4(4), 132-139.

Dyck, A., Morse, A., \& Zingales, L. (2010). Who blows the whistle on corporate fraud?. The journal of finance, 65(6), 2213-2253.

Eisenhardt, K. M. (1989). Agency theory: An assessment and review. Academy of management review, 14(1), 57-74.

Endicott, L., Bock, T., \& Narvaez, D. (2003). Moral reasoning, intercultural development, and multicultural experiences: Relations and cognitive underpinnings. International Journal of Intercultural Relations, 27(4), 403419. https://doi.org/10.1016/S0147-1767(03)00030-0

Engko, C., \& Gudono, G. (2007). Pengaruh Kompleksitas Tugas dan Locus of Control terhadap Hubungan antara Gaya Kepemimpinan dan Kepuasan Kerja Auditor. Jurnal Akuntansi dan Auditing Indonesia, 11(2).

Futri, P. S. (2014). Pengaruh Independensi, Profesionalisme, Tingkat Pendidikan, Etika Profesi, Pengalaman, Kepuasan Kerja Auditor pada Kualitas Audit Kantor Akuntan Publik di Bali. Jurnal Akuntansi, 7(2), $444-461$.

Badera, I. D. N. ., \& Jati, I. K. (2020). Moral reasoning, whistleblowing intention, and audit judgement moderate the effect of ethical sensitivity on internal audit quality. International Research Journal of Management,

IT and Social Sciences, 7(6), 42-53. https://doi.org/10.21744/irjmis.v7n6.1004 
Ghozali, I. (2016). Aplikasi Analisis Multivariate Dengan Program SPSS. Semarang: Badan Penerbit Universitas Diponegoro. Greenhalgh-spencer, H.(2005). Performance Theories in Education: Power, Pedagogy,. Educational Studies, 95.

Ghozali, I. (2017). Econometrics Theory, Concepts, and Applications with SPSS 17. Semarang: Diponegoro University Publishing Agency.

Govindarajan, V. (1986). Decentralization, strategy, and effectiveness of strategic business units in multibusiness organizations. Academy of Management Review, 11(4), 844-856.

Hartanto, J. (2001). Analisis \& Design Sistem Informasi Pendekatan Terstruktur Teori dan Praktek Aplikasi Bisnis, edisi2. Andi, Yogyakarta.

Herliansyah, Y., \& Ilyas, M. (2006). Pengaruh pengalaman auditor terhadap penggunaan bukti tidak relevan dalam auditor judgment. SNA 9 Padang, 23-26.

Hogarth, R. M., \& Einhorn, H. J. (1992). Order effects in belief updating: The belief-adjustment model. Cognitive psychology, 24(1), 1-55. https://doi.org/10.1016/0010-0285(92)90002-J

Jamilah, S. ZF, dan GC (2007). "Pengaruh Gender, Tekanan Ketaatan, dan Kompleksitas Tugas Terhadap Audit Judgment". Simposium Nasional Akuntansi X Unhas Makasar.

Jennings, M. M., Lowe, D. J., \& Reckers, P. M. (1998). Causality as an influence on hindsight bias: An empirical examination of judges' evaluation of professional audit judgment. Journal of Accounting and Public Policy, 17(2), 143-167. https://doi.org/10.1016/S0278-4254(97)10003-5

Kang, Y. J., Trotman, A. J., \& Trotman, K. T. (2015). The effect of an audit judgment rule on audit committee members' professional skepticism: The case of accounting estimates. Accounting, Organizations and Society, 46, 59-76. https://doi.org/10.1016/j.aos.2015.03.001

Kristianti, I. (2012). Pengaruh tipe kepribadian dan penerimaan perilaku disfungsional terhadap audit judgment. Universitas Kristen Satya Wacana.

Miceli, R., Sotgiu, I., \& Settanni, M. (2008). Disaster preparedness and perception of flood risk: A study in an alpine valley in Italy. Journal of environmental psychology, 28(2), 164-173. https://doi.org/10.1016/j.jenvp.2007.10.006

Mohd-Sanusi, Z., \& Mohd-Iskandar, T. (2007). Audit judgment performance: assessing the effect of performance incentives, effort and task complexity. Managerial Auditing Journal.

Muhsyi, Abdul. 2013. Pengaruh Time Budget Pressure, Risiko Kesalahan, dan Kompleksitas terhadap Kualitas Audit. Skripsi. Jakarta: Universitas Islam Negeri Syarif Hidayattulah.

Mukino, M., Purnomo, E., \& Suntoro, I. (2016). Penerapan Model Moral Reasoning untuk Membentuk Moralitas dan Karakter Siswa pada Pkn. Jurnal Studi Sosial, 4(1).

Mulyadi. (2013). Pengaruh Pengalaman Kerja, Kompetensi, Independensi, Akuntabilitas, Profesionalisme, dan Kompleksitas Tugas Auditor Terhadap Kualitas Audit (Studi Empiris Pada KAP Surakarta Dan Jogja). BHIRAWA, 1(2, 74-89.

Murray, K. B., \& Schlacter, J. L. (1990). The impact of services versus goods on consumers' assessment of perceived risk and variability. Journal of the Academy of Marketing science, 18(1), 51-65.

Mustika, P. L. K., Stoeckl, N., \& Farr, M. (2016). The potential implications of environmental deterioration on business and non-business visitor expenditures in a natural setting: A case study of Australia's Great Barrier Reef. Tourism Economics, 22(3), 484-504.

Mutmainah, S. (2006). Modul Akuntansi Keperilakuan. Universitas Diponegoro Semarang.

Patel, A. D. (2003). Language, music, syntax and the brain. Nature neuroscience, 6(7), 674-681.

Putra, I. G. C. (2013). Kualitas Audit Kantor Akuntan Publik Di Bali Ditinjau Dari Time Budget Pressure, Risiko Kesalahan, Dan Kompleksitas Audit. Jurnal Ilmiah Akuntansi dan Humanika, 2(2).

Ratha, I. M. D. K., \& Ramantha, I. W. (2015). Pengaruh Due Professional Care, Akuntabilitas, Kompleksitas Audit, dan Time Budget Pressure Terhadap Kualitas Audit. E-Jurnal Akuntansi Universitas Udayana, 13(1), $311-339$.

Raya, K., Chang, L., Bashir, A., Cobos-Martinez, J. J., Gutiérrez-Guerrero, L. X., Roberts, C. D., \& Tandy, P. C. (2016). Structure of the neutral pion and its electromagnetic transition form factor. Physical Review D, 93(7), 074017.

Sanusi, Z. M., Iskandar, T. M., \& Poon, J. M. (2007). Effects of goal orientation and task complexity on audit judgment performance. Management \& Accounting Review (MAR), 6(2), 123-139.

Sawyer, R. K. (Ed.). (2005). The Cambridge handbook of the learning sciences. Cambridge University Press.

Sunarsih, N. (2017). Influence of Organizational Climate, Motivation, and Job Satisfaction on Employee Performance. Review of Integrative Business and Economics Research, 6, 262. 
Suprasto, H. B., Ariyanto, D., Jati, I. K., Widhiyani, N. L. S., \& Suryanawa, I. K. (2017). Ability of religiosity and emotional intelligence to moderate the effect of role conflict, role ambiguity, role overload, and job insecurity on burnout of tax consultants in Bali province. Journal of Finance and Accounting, 8(18), 7-15.

Suriana, C. (2014). Maximizing Construction Project and Investment Budget Eficiency with value Engineering. Kompas Gramedia, Jakarta.

Swart, K. W. (2013). The sense of decadence in nineteenth-century France (Vol. 7). Springer Science \& Business Media.

Tangsakul, P., \& Ussahawanitchakit, P. (2015). Moral reasoning of tax auditors in Thailand: an empirical investigation of the antecedents and Consequences. The Business \& Management Review, 7(1), 134.

Wardoyo, T. S., \& Seruni, P. A. (2011). Pengaruh Pengalaman dan Pertimbangan Profesional Auditor Terhadap Kualitas Bahan Bukti Audit yang Dikumpulkan (Studi Kasus Pada Kantor Akuntansi Publik di Bandung). Akurat Jurnal Ilmiah Akuntansi, 2(06).

Windsor, C. A. (2002). Auditors' predisposition to provide fair judgments: Australian evidence of auditors' level of moral reasoning. Australian Accounting Review, 12(27), 51-58.

Yustrianthe, R. H. (2012). Beberapa faktor yang mempengaruhi audit judgment auditor pemerintah. Jurnal Dinamika Akuntansi, 4(2).

Badera, I. D. N. ., \& Jati, I. K. (2020). Moral reasoning, whistleblowing intention, and audit judgement moderate the effect of ethical sensitivity on internal audit quality. International Research Journal of Management, IT and Social Sciences, 7(6), 42-53. https://doi.org/10.21744/irjmis.v7n6.1004 